\title{
Pengaruh Bantuan Lembaga Pemerintah terhadap Orientasi Pembelajaran, Inovasi, dan Kinerja Usaha Berskala Mikro, Kecil, \& Menengah
}

\author{
Inka Awali Fauziyah, Imam Baihaqi, dan Satria Fadil Persada \\ Departemen Manajemen Bisnis, Institut Teknologi Sepuluh Nopember (ITS) \\ e-mail: ibaihaqi@mb.its.ac.id
}

\begin{abstract}
Abstrak-Di Indonesia, usaha berskala mikro, kecil, dan menengah atau UMKM berperan besar dalam pembangunan ekonomi. Jika dilihat dari pertumbuhannya, setiap tahun UMKM mengalami peningkatan. Namun peningkatan tersebut hanya dari segi kuantitas, tidak diimbangi oleh peningkatan kualitas. Salah satu peranan yang dapat memberdayakan serta mendukung UMKM untuk bertahan dan mengembangkannya adalah peran lembaga pemerintah. Selain bantuan dari lembaga pemerintah, faktor lain yang dapat mengembangkan UMKM dari segi internal yaitu orientasi pembelajaran. UMKM yang memiliki komitmen untuk terus belajar dapat meningkatkan kemampuan inovasinya karena inovasi berkaitan erat dengan lingkungan yang terus berubah. Penelitian ini bertujuan untuk mengidentifikasi pengaruh bantuan yang diberikan lembaga pemerintah terhadap orientasi pembelajaran, inovasi, dan kinerja bisnis pada UMKM. Data penelitian didapatkan dari survei yang menggunakan kuesioner. Metode PLS-SEM digunakan sebagai teknik analisis data untuk menguji model yang telah dibentuk. Dari 71 responden yang didapatkan, hasil penelitian ini menunjukkan bahwa bantuan lembaga pemerintah berpengaruh positif terhadap inovasi, orientasi pembelajaran berpengaruh positif terhadap inovasi, orientasi pembelajaran tidak memoderasi hubungan bantuan lembaga pemerintah dan inovasi namun bersifat memediasi, serta inovasi memiliki pengaruh positif terhadap kinerja bisnis.
\end{abstract}

Kata Kunci-Batuan Pemerintah, Inovasi, Kinerja Bisnis, Orientasi Pembelajaran, UMKM

\section{PENDAHULUAN}

$\mathrm{U}$ SAHA berskala Mikro, Kecil, dan Menengah yang selanjutnya akan disebut UMKM, berperan dalam hal pembaruan industri, penciptaan lapangan kerja, pertumbuhan ekspor, dan produktivitas [1]. Menurut [2], selain UMKM telah menunjukkan peranannya dalam penciptaan kesempatan kerja, UMKM juga sebagai salah satu sumber penting bagi pertumbuhan Produk Domestik Bruto (PDB). Selain di Indonesia, UMKM juga telah menjadi tulang punggung perekonomian Association of Southeast Asian Nations (ASEAN) karena sekitar 88,8-99,9\% bentuk usaha di ASEAN adalah UMKM dengan penyerapan tenaga kerja mencapai 51,7-97,2\% [3]. Uraian di atas menunjukkan bahwa UMKM memiliki peranan yang besar bagi suatu negara, khususnya di Indonesia.

Meskipun jumlah UMKM dari tahun ke tahun mengalami kenaikan , peningkatan UMKM hanya dari segi kuantitas, belum diimbangi oleh meratanya peningkatan kualitas [4]. Dalam upaya peningkatan kualitas pada UMKM, tentunya tidak terlepas dari hambatan-hambatan yang ada, seperti kurangnya pembiayaan, kesulitan dalam memanfaatkan teknologi, keterbatasan kemampuan manajerial, produktivitas rendah, kesulitan memperbesar pangsa pasar, persaingan yang saling mematikan, dll. Hambatan-hambatan tersebut selain memperlambat usaha, juga dapat mematikan UMKM.

Salah satu peranan yang bisa melakukan pemberdayaan dan juga mendukung UMKM untuk dapat bertahan serta mengembangkannya adalah peran lembaga pemerintah. Terlebih untuk pemerintah daerah, karena menurut Ketua Kemendagri [5], pemerintah daerah memiliki peran yang sangat strategis dalam menumbuh-kembangkan UMKM di daerah. Selain berperan sebagai pembuat kebijakan, pemerintah daerah juga merupakan lini pemerintahan yang paling dekat dengan UMKM dalam memberikan programprogram yang bisa meningkatkan kinerja UMKM. Bantuan pemerintah memiliki pengaruh yang signifikan terhadap jumlah penjualan dan karyawan [6]. Sedangkan,bantuan pemerintah memiliki pengaruh terhadap inovasi perusahaan. Dari uraian di atas, dapat disimpulkan bahwa bantuan pemerintah sangat dibutuhkan untuk mengembangkan UMKM [7], [8].

Saat ini, pemerintah mengembangkan UMKM melalui pemerintah kota/kabupaten secara langsung ataupun melalui lembaga perangkat daerah. Namun seringkali kegiatan pengembangan tersebut dilakukan oleh lembaga pemerintah seperti Dinas Tenaga Kerja, Dinas Koperasi dan Usaha Mikro, dan Dinas Perdagangan. Program atau bantuan yang diberikan pemerintah diantaranya penyaluran dana untuk pemberdayaan dan pembinaan UMKM, mempercepat perizinan dalam berusaha, penyuluhan dan pengurusan perizinan gratis secara berkala, pemberian modal usaha, penurunan bunga pinjaman modal, dan lain-lainnya.

Selain bantuan pemerintah, faktor lain yang dapat mengembangkan UMKM dari segi internal adalah orientasi pembelajaran yang kuat. Orientasi pembelajaran mencakup transfer pembelajaran dari individu ke kelompok, komitmen untuk belajar, keterbukaan terhadap dunia luar, komitmen keseluruhan untuk pengetahuan, sistem untuk mengembangkan pembelajaran, dan mekanisme untuk memperbarui organisasi [9]. Sebagian besar pembelajaran terjadi melalui interaksi organisasi dan pengamatan lingkungan [10]. Organisasi yang berkomitmen untuk terus belajar dapat meningkatkan kemampuan inovasinya karena inovasi berkaitan erat dengan lingkungan yang krusial seperti ketidakpastian permintaan pelanggan, turbulensi teknologi, 


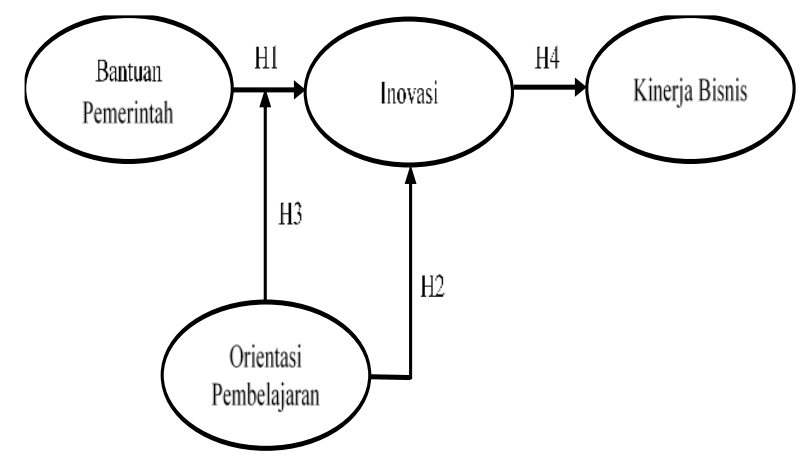

Gambar 1. Kerangka Penelitian

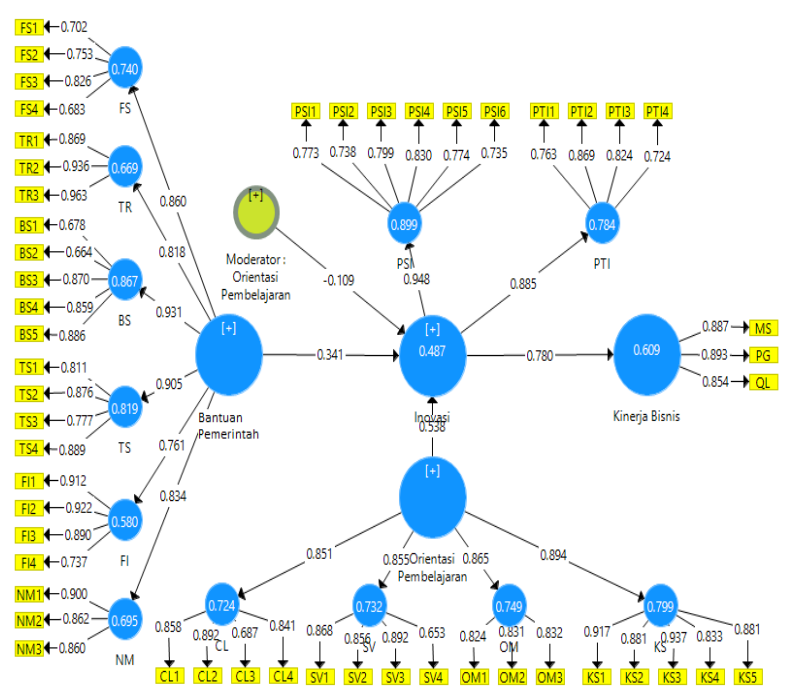

Gambar 2. Olah Data PLS-SEM

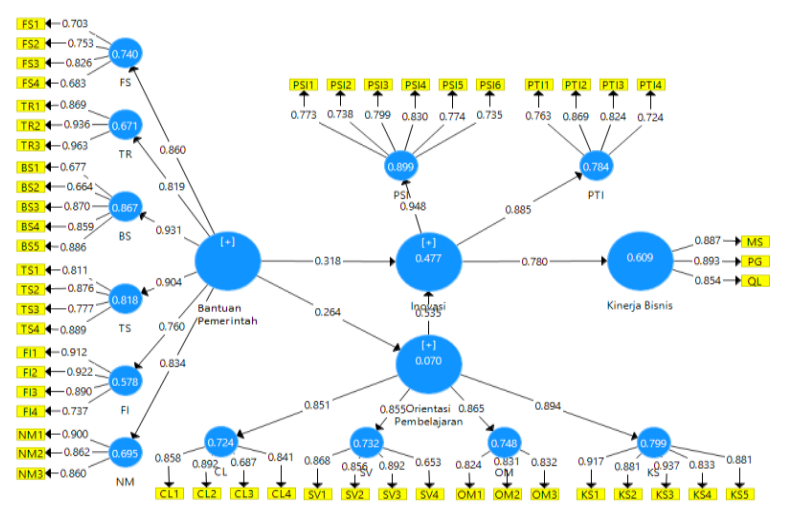

Gambar 3. Olah Data PLS-SEM Variabel Mediasi

dan persaingan yang penuh dengan ketidakpastian. Jika perusahaan mengedepankan orientasi pembelajaran maka akan tercipta pengembangan produk/jasa baru dan metode operasi yang kreatif [11]. Dengan kata lain, inovasi perusahaan akan terus terjadi jika perusahaan memiliki orientasi untuk terus belajar. Kinerja inovasi dapat memengaruhi kinerja bisnis manufaktur dan jasa di Indonesia [12]. Hal tersebut mendukung penelitian [13] yang menyatakan inovasi menjadi faktor dominan dalam mempertahankan daya saing di seluruh dunia. Pada penelitian ini, penulis akan mencoba mengaplikasikan model penelitian yang dikembangkan oleh Model empiris yang disarankan oleh Young Park \& Wook Kim (2010). Model empiris yang disarankan oleh Young Park \& Wook Kim (2010) dijadikan penulis untuk membentuk model awal. Selanjutnya model tersebut dikembangkan dengan menambahkan variabel yang emiliki keterkaitan, sampai pada menghasilkan model untuk mengetahui pengaruh bantuan lembaga pemerintah terhadap orientasi pembelajaran, inovasi, dan kinerja bisnis.

\section{KERANGKA DAN HIPOTESIS PENELITIAN}

Program publik yang mendukung R\&D seperti subsidi biaya baik langsung oleh hibah atau secara tidak langsung oleh kredit pajak dan program bantuan pemerintah lainnya seperti bantuan teknologi, bantuan modal, informasi dan layanan internet, program pelatihan tenaga kerja berpengaruh sangat penting dan sering digunakan juga dapat meningkatkan kegiatan inovasi swasta dan orisinalitas mereka [15]. Bantuan pemerintah untuk kegiatan R\&D telah berkontribusi terhadap kinerja inovasi pada perusahaan di Turki dan Polandia [8]. Berdasarkan Gambar 1, maka dapat dibentuk hipotesis berikut: H1 : Bantuan pemerintah memiliki pengaruh positif terhadap inovasi. Pembelajaran akan terjadi melalui interaksi yang terjadi di organisasi dan pengamatan lingkungan. Terkait dengan inovasi, ketidakpastian permintaan pelanggan, turbulensi teknologi, dan ketidakpastian dalam kompetisi adalah faktor lingkungan yang penting [16]. Oleh karena itu, organisasi yang berkomitmen untuk belajar dapat meningkatkan kemampuan inovasinya. Ditemukan bahwa satu set nilai-nilai pengetahuan-pertanyaan melalui komitmen untuk pembelajaran, visi bersama, keterbukaan pikiran, dan berbagi pengetahuan intraorganisasi membuat perusahaan mencoba untuk membuat ide baru, mencari cara baru untuk melakukan sesuatu, mengembangkan produk/jasa baru dan metode operasi yang kreatif [11]. Berdasarkan penjelasan hubungan orientasi pembelajaran dan inovasi di atas, dapat dibentuk hipotesis sebagai berikut: $\mathrm{H} 2$ : Orientasi pembelajaran memiliki pengaruh positif terhadap inovasi

Penjelasan terkait hubungan pemerintah dan inovasi serta hubungan orientasi pembelajaran dan inovasi. Jika kedua hubungan tersebut memiliki pengaruh yang positif, diduga dengan adanya orientasi pembelajaran, bantuan pemerintah semakin meningkatkan inovasi. Hal tersebut dikarenakan UMKM bisa memanfaatkan bantuan yang diberikan pemerintah sebagai wadah pembelajaran bagi usahanya, misalnya melalui bantuan pelatihan, networking \& mentoring, dan lain-lain. Berdasarkan uraian di atas, terbentuklah hipotesis sebagai berikut: H3 : Orientasi pembelajaran memoderasi hubungan bantuan pemerintah dan inovasiKemampuan untuk berinovasi untuk memenuhi tantangan ini merupakan penentu utama kesuksesan perusahaan [17]. Peran positif dari inovasi perusahaan pada kinerja perusahaan telah didukung oleh banyak studi teoritis dan empiris dari pengembangan produk baru, adopsi teknologi dan difusi, peningkatan proses, dan inovasi [10]. Sehingga terbentuklah hipotesis sebagai berikut; H4: Inovasi memiliki pengaruh positif terhadap kinerja bisnis. 
Tabel 1.

Hasil Uji AVE

\begin{tabular}{lr}
\hline \hline \multicolumn{1}{c}{ Variabel - Dimensi } & AVE \\
\hline Bantuan Pemerintah & 0,5089 \\
FS & 0,5524 \\
TR & 0,8532 \\
BS & 0,6357 \\
TS & 0,7048 \\
FI & 0,7541 \\
NM & 0,7637 \\
Orientasi Pembelajaran & 0,5407 \\
CL & 0,6778 \\
SV & 0,6774 \\
OM & 0,6872 \\
KS & 0,7931 \\
Inovasi & 0,5229 \\
PSI & 0,6016 \\
PTI & 0,6352 \\
Kinerja Bisnis & 0,7712 \\
Moderator & 1,0000 \\
\hline \hline
\end{tabular}

Tabel 2.

Hasil Uji Reliabilitas

\begin{tabular}{ccc}
\hline \hline Variabel - Dimensi & Cronbach's Alpha & CR \\
\hline Bantuan Pemerintah & 0,9553 & 0,9593 \\
FS & 0,7290 & 0,8308 \\
TR & 0,9129 & 0,9457 \\
BS & 0,8515 & 0,8957 \\
TS & 0,8591 & 0,9050 \\
FI & 0,8880 & 0,9241 \\
NM & 0,8460 & 0,9064 \\
Orientasi Pembelajaran & 0,9419 & 0,9490 \\
CL & 0,8385 & 0,8929 \\
SV & 0,8370 & 0,8923 \\
OM & 0,7724 & 0,8683 \\
KS & 0,9344 & 0,9503 \\
Inovasi & 0,8982 & 0,9162 \\
PSI & 0,8671 & 0,9004 \\
PTI & 0,8062 & 0,8739 \\
Kinerja Bisnis & 0,8515 & 0,9100 \\
Moderator & 1,0000 & 1,0000 \\
\hline \hline
\end{tabular}

\section{METODE PENELITIAN}

Penelitian ini merupakan penelitian kuantitatif-konklusifdeskriptif. Teknik pengambilan data dalam penelitian ini menggunakan teknik atau metode multiple cross sectional. Data pada penelitian ini terdiri dari data sekunder yang didapatkan dari studi literatur dan data primer yang didapatkan dari survei menggunakan kuesioner. Kuesioner terdiri dari pertanyaan umum yang memuat demografi responden dan UMKM, dan juga pertanyaan inti yang memuat empat variabel engan total 15 dimensi. Variabel bantuan pemerintah memiliki dimensi bantuan finansial (FS), pelatihan (TR), bantuan bisnis (BS), bantuan teknologi (TS), fasilitas dan infrastruktur (FI), serta jaringan dan pembimbingan (NM) [18]. Variabel orientasi pembelajaran memiliki dimensi komitmen untuk pembelajaran (CL), visi bersama (SV), keterbukaan pikiran (OM), dan berbagi pengetahuan intraorganisasi (KS) [11]. Lalu variabel inovasi memiliki dimensi inovasi produk dan layanan (PSI) serta inovasi proses dan teknik (PTI) [17]. Sedangkan kinerja bisnis diukur dari pertumbuhan laba (PG), pangsa pasar berada (MS), kualitas yang dirasakan pelanggan dari produk/layanan (QL). Setiap dimensi terdiri dari beberapa indikator pertanyaan pada kuesioner yang dievaluasi berdasarkan skala likert. Skala likert yang digunakan memiliki nilai 1 yang mewakili "Saya sangat tidak setuju" sampai 5 yang mewakili "Saya sangat setuju". Kuesioner
Tabel 3.

Hasil Uji R ${ }^{2}$

\begin{tabular}{lc}
\hline \hline Variabel Endogen & $R$-square \\
\hline Inovsi & 0,4866 \\
Kinerja Bisnis & 0,6086 \\
\hline \hline
\end{tabular}

Tabel 4.

Hasil Uji Hipotesis Penelitian

\begin{tabular}{lcrc}
\hline \hline & $\begin{array}{c}\text { Original } \\
\text { Sample }\end{array}$ & $\begin{array}{c}T \\
\text { Statistics }\end{array}$ & $\begin{array}{c}P \\
\text { Values }\end{array}$ \\
\hline $\begin{array}{l}\text { Bantuan Pemerintah } \rightarrow \text { Inovasi } \\
\text { Orientasi Pembelajaran } \rightarrow\end{array}$ & 0,3407 & 3,2865 & 0,0010 \\
$\begin{array}{l}\text { Inovasi } \\
\text { Moderator: Orientasi }\end{array}$ & 0,5384 & 6,4303 & 0,0000 \\
$\begin{array}{l}\text { Pembelajaran } \\
\text { Inovasi } \rightarrow \text { Kinerja Bisnis }\end{array}$ & $-0,1089$ & 0,9998 & 0,3176 \\
\hline \hline
\end{tabular}

Tabel 5.

Hasil Uji Hipotesis Variabel Mediasi

\begin{tabular}{|c|c|c|c|}
\hline & $\begin{array}{l}\text { Original } \\
\text { Sample }\end{array}$ & $\begin{array}{c}T \\
\text { Statistics }\end{array}$ & $\begin{array}{c}P \\
\text { Values }\end{array}$ \\
\hline $\begin{array}{l}\text { Bantuan Pemerintah } \rightarrow \text { Inovasi } \\
\text { Orientasi Pembelajaran } \rightarrow\end{array}$ & 0,3179 & 3,1785 & 0,0015 \\
\hline Inovasi & 0,5349 & 6,7852 & 0,0000 \\
\hline $\begin{array}{l}\text { Bantuan Pemerintah } \rightarrow \text { Orientasi } \\
\text { Pembelajaran }\end{array}$ & 0,2644 & 2,4037 & 0,0164 \\
\hline Inovasi $\rightarrow$ Kinerja Bisnis & 0,7801 & 18,6619 & 0,0000 \\
\hline
\end{tabular}

disebarkan pertama kalinya untuk keperluan pilot test. Setelah mengetahui hasil positif dari pilot test, kuesioner disebarkan kembali pada Desember 2018 sampai Januari 2019 dengan metode yang sama untuk mendapatkan data penelitian yang lebih banyak. Metode pengambilan sampel yang digunakan adalah non-probability sampling, khususnya convenience sampling di wilayah Surabaya. Jumlah data yang terkumpul dalam penelitian ini yaitu 71 data. Setelah data terkumpul, SPSS dan SmartPLS digunakan untuk menganalisis data.

\section{ANALISIS DATA}

\section{A. Demografi}

Dari 71 respoden pada penelitian ini, sebesar 62 berskala mikro karena memiliki penjualan pertahun maksimal 300 juta, 8 usaha memiliki penjualan pertahun lebih dari 300 juta sampai 2,5 miliar yang artinya berskala kecil, sedangkan 1 lainnya berskala menengah atau memiliki penjualan pertahun lebih dari 2,5 miliar sampai 50 miliar. Tidak ada responden yang penjualan pertahunnya melebihi 50 miliar. Hal ini menunjukkan bahwa semua responden pada penelitian ini merupakan UMKM, bukan usaha besar. Mayoritas sektor usaha milik responden adalah industri pengolahan (sebesar 46,5\%). Sedangkan UMKM lain yang menjadi samType equation here.pel penelitian ini bergerak di sektor perdagangan, hotel, dan restoran $(33,8 \%)$, jasa-jasa $(18,3 \%)$, dan juga keuangan, persewaan, dan jasa perusahaan (18,3\%). Ditinjau dari segi kendala usaha, 32,4\% memiliki kendala utama pada pemasaarannya, lalu $28,2 \%$ terkendala pemodalan/likuiditas, $25,4 \%$ terkendala pada tenaga kerja, $7 \%$ terkendala pada bahan baku/barang dagangan, sedangkan 7\% lainnya memiliki kendala utama adanya pesaing yang berarti. Dapat disimpulkan bahwa kendala utama pada mayoritas UMKM adalah kendala pemasaran. 


\section{B. Analisis Model Penelitian}

Analisis model pada penelitian ini menggunakan metode Partial Least Square Structural Equation Modelling (PLSSEM) dengan program SmartPLS 3.0. Terdapat 2 evaluasi pada model, yaitu evaluasi yang dilakukan pada outer model dan inner model. Evaluasi outer model terdiri dari uji validitas dan reliabilitas pada masing-masing variabel. Sedangkan evaluasi inner model terdiri dari uji Goodness of Fit (GoF) dan uji hipotesis antara lain; (1)Outer Model. Uji outer model dilakukan untuk mengetahui nilai validitas dan reliabilitas dari indikator pembentuk variabel. Pengujian nilai validitas dilakukan dengan convergent validity dengan melihat nilai outer loading dari setiap indikator. Kriteria untuk validitas nilai outer loading adalah jika nilai outer loading memiliki nilai $\geq 0,5$, sehingga apabila terdapat nilai outer loading yang kurang dari 0,5 maka indikator tersebut harus dikeluarkan dari model. Gambar 2 menampilkan hasil olah data dan menunjukkan bahwa semua indikator telah memenuhi syarat uji convergent validity karena memiliki outer loading yang nilainya $\geq 0,5$.

Selanjutnya akan dibahas mengenai discriminant validity dengan melihat nilai cross loading. Hasil dari cross loading telah memperlihatkan bahwa setiap indikator telah memenuhi uji discriminant validity. Hal tersebut dikarenakan setiap indikator yang dipasangkan untuk dimensi/variabelnya mempunyai nilai yang lebih besar dibandingkan dengan indikator yang dipasangkan dengan dimensi/variabel lainnya. Selain melihat nilai cross loading, discriminant validity juga dapat dilakukan menggunakan nilai average variance extracted (AVE). Kriteria nilai AVE dinyatakan valid jika nilainya lebih dari 0,5. Pada Tabel 1 terlihat bahwa semua nilai AVE lebih dari 0,5. Oleh karena itu, dapat dinyatakan bahwa semua variabel dalam penelitian telah memenuhi uji validitas.

Analisis outer model untuk menyatakan reliabilitas suatu variabel yaitu menggunakan perhitungan cronbach's alpha dan composite reliability (CR). Nilai cronbach's alpha dan composite reliability dikatakan reliabel jika nilai cronbach's alpha $\geq 0,6$ dan composite reliability $\geq 0,7$. Berdasarkan Tabel 2, dapat disimpulkan bahwa semua variabel penelitian dapat dikatakan telah memenuhi kaidah reliabel; (2) Inner Model. Pada pengujian inner model akan dilakukan penilaian terhadap variabel dari suatu model. Penilaian dilakukan melalui uji goodness of fit dan uji hipotesis. Uji goodness of fit perlu dilakukan untuk melihat apakah model penelitian sudah fit. Penilaian goodness of fit dapat dinilai dengan $R$ square $\left(\mathrm{R}^{2}\right)$ dan $Q$-square Predictive Relevance $\left(\mathrm{Q}^{2}\right)$. Nilai $\mathrm{R}^{2}$ disajikan pada Tabel 3 .

Nilai $\mathrm{R}^{2}$ variabel inovasi sebesar 0,49 atau $49 \%$. Hal ini menunjukkan bahwa persentase besarnya keragaman data pada variabel inovasi yang dapat dijelaskan oleh variabel bantuan pemerintah dan orientasi pembelajaran sebesar $49 \%$, sedangkan sisanya yaitu $51 \%$ dijelaskan oleh faktor lain di luar penelitian ini. Dengan kata lain, variabel bantuan pemerintah dan orientasi pembelajaran memengaruhi variabel bantuan pemerintah sebesar $49 \%$. Lalu untuk nilai $\mathrm{R}^{2}$ variabel kinerja bisnis yaitu 0,61 atau 61\%. Yang artinya persentase besarnya keragaman data pada variabel kinerja bisnis yang dapat dijelaskan oleh variabel inovasi sebesar $61 \%$, sedangkan sisanya yaitu $49 \%$ dijelaskan oleh faktor lain di luar penelitian ini. Dapat juga diinterpretasikan bahwa variabel inovasi memengaruhi variabel kinerja bisnis sebesar 61\%. Nilai $\mathrm{Q}^{2}$ menunjukkan kemampuan prediksi model yang dikembangkan dalam penelitian ini. Jika nilai $\mathrm{Q}^{2}>0$, maka model memiliki relevansi prediksi yang baik. Berdasarkan nilai $\mathrm{R}^{2}$ pada tabel 3, maka dapat dihitung nilai $\mathrm{Q}^{2}$ menggunakan rumus sebagai berikut.

$$
\begin{aligned}
& Q^{2}=1-\left(1-R_{1}\right)\left(1-{R_{1}}^{2}\right) \ldots\left(1-R_{\mathrm{n}}{ }^{2}\right) \\
& Q^{2}=1-(1-0,4866)(1-0,6086)=0,700
\end{aligned}
$$

Dari hasil perhitungan (2), dapat diketahui bahwa nilai $\mathrm{Q}^{2}$ yaitu sebesar 0,799. Hal ini menunjukkan bahwa model struktural penelitian telah mampu memetakan $79,9 \%$ dari kondisi sebenarnya. Sisanya, yaitu 20,1\% menunjukkan terdapat beberapa variabel dan beberapa faktor yang bisa dimasukkan ke dalam penelitian untuk membuat persamaan yang bisa memetakan kondisi sebenarnya. Berdasarkan hasil tersebut, model struktural pada penelitian ini dapat dikatakan telah memiliki relevansi prediksi yang baik [19]. Selanjutnya menghitung nilai GoF berdasarkan rumus :

$$
\begin{aligned}
& G_{\mathrm{o}} F=\sqrt{(A V E)} \times R^{2} \\
& G_{\mathrm{o}} F=\sqrt{(0,687} \times 0,5476=0,6133
\end{aligned}
$$

Model konseptual yang digunakan dalam penelitian ini menghasilkan nilai indeks GoF sebesar 0,6133, yang menunjukkan model fit yang sangat baik (GoF besar) [20]. Tahap selanjutnya adalah pengujian hipotesis dilakukan dengan melihat nilai path coefficient, hasil t-statistik dan $p$ value dari setiap variabel yang berhubungan. Karena penelitian ini menggunakan taraf signifikansi sebesar 5\% dan sampel penelitian sejumlah 71 maka nilai t-tabel adalah 1,996 .

Berdasarkan Tabel 4, nilai path coefficient atau yang ditunjukkan pada nilai original sample, semua hubungan antar variabel memiliki nilai positif kecuali hubungan moderasi. Hal ini menandakan bahwa bantuan pemerintah berpengaruh posistif terhadap inovasi, orientasi pembelajaran berpengaruh positif terhadap inovasi, inovasi berpengaruh positif terhadap kinerja bisnis, sedangkan orientasi pembelajaran yang berperan sebagai moderator antara bantuan pemerintah dan inovasi memiliki pengaruh negatif. Hasil t-statistik dan $p$-value pada Tabel 4 juga menunjukkan semua hubungan variabel memiliki pengaruh signifikan, kecuali hubungan moderasi. Dari hasil perhitungan tersebut dapat dinyatakan bahwa variabel bantuan pemerintah berpengaruh positif signifikan terhadap inovasi, orientasi pembelajaran berpengaruh positif signifikan terhadap inovasi, inovasi berpengaruh positif signifikan terhadap kinerja bisnis, sedangkan orientasi pembelajaran yang berperan sebagai moderator antara bantuan pemerintah dan inovasi berpengaruh negatif tidak signifikan.Dari hasil yang telah diuraikan di atas, dapat disimpulkan bahwa hipotesis pertama, kedua dan keempat diterima, sedangkan hipotesis ketiga ditolak. Penjelasan masing - masing hipotesis akan dibahas pada subbab diskusi.

\section{DISKUSI}

Hipotesis 1 yang diterima sesuai dengan hasil penelitian [15] yang membuktikan bahwa program publik yang mendukung $\mathrm{R} \& \mathrm{D}$ seperti subsidi biaya baik langsung oleh 
hibah atau secara tidak langsung oleh kredit pajak dan program bantuan pemerintah lainnya seperti bantuan teknologi, bantuan modal, informasi dan layanan internet, program pelatihan tenaga kerja berpengaruh sangat penting dan sering digunakan juga dapat meningkatkan kegiatan inovasi. Bantuan pemerintah, terutama untuk kegiatan R\&D telah berkontribusi terhadap kinerja inovasi pada perusahaan di Turki dan Polandia [8]. Bantuan pemerintah sangat penting bagi UKM yang menghadapi kekurangan sumber daya internal [7]. Inovasi berkaitan dengan mencoba ide-ide baru, mencari cara-cara baru yang mana tidak semua UMKM memiliki kemampuan terhadap hal tersebut. Dengan adanya bantuan dari pemerintah, dapat membantu UMKM yang mengalami keterbatasan dan kendala inovasi dalam mengembangkan usahanya. Oleh karena itu bantuan pemerintah memiliki pengaruh positif signifikan terhadap inovasi yang dimiliki oleh UMKM.

Hipotesis 2 yang dinyatakan diterima kebenarannya pada penelitian ini sejalan dengan penelitian Keskin [11] yang menyatakan bahwa jika perusahaan mengedepankan orientasi pembelajaran maka akan tercipta pengembangan produk/jasa baru dan metode operasi yang kreatif. Pembelajaran akan terjadi melalui interaksi yang terjadi di UMKM dan pengamatan lingkungan. Faktor yang membuat UMKM melakukan pengamatan lingkungan adalah ketidakpastian permintaan pelanggan, turbulensi teknologi, dan ketidakpastian dalam kompetisi. Yang mana faktor-faktor tersebut sangat berkaitan dengan inovasi [16]. UMKM yang memiliki pengetahuan ataupun berkemampuan tinggi untuk belajar tidak mungkin melewatkan peluang yang diciptakan oleh permintaan pasar karena UMKM mampu untuk memahami dan mengantisipasi kebutuhan pelanggan [16], [21]. Oleh karena UMKM yang berkomitmen untuk belajar dapat meningkatkan kemampuan inovasinya, maka orientasi pembelajaran memiliki pengaruh positif signifikan terhadap inovasi yang dimiliki oleh UMKM. Walaupun bantuan pemerintah berpengaruh positif terhadap inovasi dan orientasi pembelajaran berpengaruh positif terhadap inovasi, ternyata dugaan tentang orientasi pembelajaran akan semakin meningkatkan hubungan bantuan pemerintah terhadap inovasi tidak dibenarkan pada penelitian ini. Penulis mencoba melihat kemungkinan lain dengan menguji hubungan mediasi seperti pada Gambar 3.

Berdasarkan hasil uji hubungan mediasi yang tersaji pada Tabel 5 di bawah ini, ternyata bantuan pemerintah memiliki pengaruh positif signifikan terhadap orientasi pembelajaran. Selain itu signifikansi hubungan orientasi pembelajaran terhadap inovasi juga mengalami kenaikan dari model sebelumnya yang menggunakan variabel moderator. Hal ini menandakan bahwa orientasi pembelajaran tidak bertindak sebagai variabel moderator,namun sebagai variabel mediator. Semakin tingginya bantuan pemerintah yang diberikan melalui kegiatan yang dapat mendorong orientasi pembelajaran pada UMKM, maka akan semakin tinggi pula inovasi UMKM yang akan terbentuk. Demikian juga, akan semakin baik jika UMKM yang mendapatkan bantuan pemerintah menjadikan bentuk bantuan tersebut sebagai orientasi pembelajaran di usahanya untuk meningkatkan inovasi. Karena hanya memiliki orientasi pembelajaran saja tidak akan membuat bantuan tersebut akan lebih meningkata inovasi. Hubungan positif antara inovasi dan kinerja organisasi pada penelitian ini konsisten dengan penelitian sebelumnya yang dilakukan [22] [23] dan [24]. Indikator kinerja bisnis yang digunakan pada penelitian ini mempertimbangkan kinerja kompetitor dari segi laba, pangsa pasar dan kualitas produk/layanan. inovasi menjadi faktor dominan dalam mempertahankan daya saing di seluruh dunia. Sehingga UMKM yang mampu berinovasi akan dapat meningkatkan kinerja bisnisnya [13]. Oleh karena itu, pada penelitian ini inovasi berpengaruh positif signifikan terhadap kinerja bisnis.

\section{KESIMPULAN}

Bantuan pemerintah untuk UMKM bisa didapatkan melalui Pemerintah Kota, Dinas Tenaga Kerja, Dinas Koperasi dan Usaha Mikro, Dinas Perdagangan, dan lembaga pemerintahan lainnya. Bentuk-bentuk dukungan/bantuan yang bisa didapatkan yaitu bantuan finansial, pelatihan, bantuan bisnis, bantuan teknologi, fasilitas dan infrastruktur, networking dan pembinaan. Bantuan yang paling berpeluang besar untuk bisa didapatkan oleh UMKM adalah pelatihan.

Berdasarkan analisis data menggunakan PLS-SEM, diketahui bahwa bantuan pemerintah berpengaruh posistif signifikan terhadap inovasi, orientasi pembelajaran berpengaruh positif signifikan terhadap inovasi, inovasi berpengaruh positif signifikan terhadap kinerja bisnis, sedangkan orientasi pembelajaran tidak berperan sebagai moderator antara bantuan pemerintah dan inovasi, melainkan sebagai mediator. Hal ini menunjukkan bahwa hipotesis pertama, kedua dan keempat diterima, sedangkan hipotesis ketiga ditolak.

Dalam upaya peningkatan kualitas UMKM, lembaga pemerintah perlu memberikan bantuan yang bersifat intens namun juga tidak membatasi ruang gerak UMKM untuk ikut serta aktif/terlibat dalam pengembangan. Lalu akan lebih baik jika bantuan pemerintah lebih difokuskan pada peningkatan kapabilitas internal yang mengarah kepada orientasi pembelajaran.

Untuk UMKM, baik yang telah mendapatkan bantuan dari pemerintah ataupun belum. Akan lebih baik jika memiliki orientasi pembelajaran pada usahanya. Karena orientasi pembelajaran mendukung terbentuknya inovasi dan inovasi dapat meningkatkan kinerja bisnis. Lalu untuk UMKM yang telah mendapatkan bantuan dari pemerintah, sebaiknya bisa mengoptimalkan bantuan yang ada agar memberikan dampak yang signifikan untuk usahanya. UMKM harus berperan aktif untuk memanfaatkan peluang yang telah diberikan pemerintah.

Saran untuk penelitian selanjutnya adalah melakukan generalisasi hasil penelitian dengan menggunakan responden dengan lingkup yang lebih luas seperti tingkat regional ataupun nasional. Peneliti juga menyarankan untuk mengambil sampel dengan mempertimbangkan proporsi pemberi bantuan agar model penelitian dapat dikembangkan lebih mendalam dan lebih representatif. Selain itu, penelitian kedepannya dapat menguji lebih lanjut tentang hubungan bantuan pemerintah terhadap inovasi dengan menggunakan mediator orientasi pembelajaran atau variabel lainnya seperti orientasi pemasaran. 


\section{UCAPAN TERIMA KASIH}

Penulis mengucapkan terima kasih kepada seluruh pemilik atau pengelola UMKM yang telah bersedia menjadi responden dalam penelitian ini.

\section{DAFTAR PUSTAKA}

[1] S. Doh and B. Kim, "Government support for SME innovations in the regional industries: The case of government financial support program in South Korea," Res. Policy, vol. 43, no. 9, pp. 1557-1569, Nov. 2014

[2] A. Rahmana, Peranan teknologi informasi dalam peningkatan daya saing usaha kecil menengah. Universitas Widyatama, 2009.

[3] Metrotvnews.com, "Jokowi: UMKM Tulang Punggung Ekonomi RI \& ASEAN," 2016. [Online]. Available: http://ekonomi.metrotvnews.com/read/2016/02/17/485451/jokowiumkm-tulang-punggung-ekonomi-ri-asean. [Accessed: 26-Sep-2018].

[4] A. Anggarani, W. P. Tyas, and V. I. Safitri, "Penguatan Sektor Umkm Sebagai Strategi Menghadapi Mea 2015," J. Ekon., vol. 5, no. 1, pp 42-48, 2014.

[5] Keuda Kemendagri, "Peran Pemda dalam Tumbuhkan UKM," 2013. [Online]. Available: http://keuda.kemendagri.go.id/artikel/detail/40peran-pemda-dalam-tumbuhkan-ukm.

[6] C. A. Cancino, C. A. Bonilla, and M. Vergara, "The impact of government support programs for the development of businesses in Chile," Manag. Decis., vol. 53, no. 8, pp. 1736-1754, Sep. 2015.

[7] K.-N. Kang and H. Park, "Influence of government R\&D support and inter-firm collaborations on innovation in Korean biotechnology SMEs," Technovation, vol. 32, no. 1, pp. 68-78, Jan. 2012.

[8] K. Szczygielski, W. Grabowski, M. T. Pamukcu, and V. S. Tandogan, "Does government support for private innovation matter? Firm-level evidence from two catching-up countries," Res. Policy, vol. 46, no. 1 , pp. 219-237, Feb. 2017.

[9] F. T. Mavondo, J. Chimhanzi, and J. Stewart, "Learning orientation and market orientation," Eur. J. Mark., vol. 39, no. 11/12, pp. 1235-1263, Nov. 2005.

[10] R. J. Calantone, S. T. Cavusgil, and Y. Zhao, "Learning orientation, firm innovation capability, and firm performance," Ind. Mark. Manag., vol. 31, no. 6, pp. 515-524, Sep. 2002.

[11] H. Keskin, "Market orientation, learning orientation, and innovation capabilities in SMEs," Eur. J. Innov. Manag., vol. 9, no. 4, pp. 396417, Oct. 2006
[12] D. Prajogo, The Relationship between Innovation and Business Performance-A Comparative Study between Manufacturing and Service Firms, vol. 13. 2006.

[13] C. Yeh-Yun Lin and M. Yi-Ching Chen, "Does innovation lead to performance? An empirical study of SMEs in Taiwan," Manag. Res. News, vol. 30, no. 2, pp. 115-132, 2007.

[14] J. Young Park and S. Wook Kim, "An empirical model to assess the influence of the government's research and development program on Korean small and medium enterprise (SME) performance," Asian J. Qual., vol. 11, no. 3, pp. 288-302, Nov. 2010.

[15] P. Hanel, G. Sabourin, B. Plaus, N. Traore, F. Gault, and S. Canada, "Impact of Government Support Programs on Innovation by Canadian manufacturing firms Paper for the International Conference : Evaluation of Government funded R \& D Activities , from ZEW ( Germany ). A . Bourezak provided competent computer work . The usual," Int. Conf. Eval. Gov. Funded R\&D Act., pp. 15-16, 2003.

[16] D. Cahill, "Entrepreneurial Orientation or Pioneer Advantage," Acad. Manag. Rev., vol. 21, no. 3, pp. 603-605, 1996.

[17] J. Rhodes, R. Hung, P. Lok, B. Ya-Hui Lien, and C. Wu, "Factors influencing organizational knowledge transfer: implication for corporate performance," J. Knowl. Manag., vol. 12, no. 3, pp. 84-100, May 2008

[18] A. K. Meru and M. Struwig, "An Evaluation of the Entrepreneurs' Perception of Business-Incubation Services in Kenya," Int. J. Bus. Adm., vol. 2, no. 4, pp. 112-121, 2011.

[19] I. G. N. M. Jaya and I. M. Sumertajaya, "Permodelan Persamaan Struktural Dengan Partial Least Square," in Seminar Nasional Matematika dan Pendidikan Matematika, 2008, pp. 118-132.

[20] M. Wetzels, G. Odekerken-Schröder, and C. van Oppen, "Using PLS Path Modeling for Assessing Hierarchical Construct Models: Guidelines and Empirical Illustration," MIS Q., vol. 33, no. 1, pp. $177-$ 195, 2009.

[21] F. Damanpour, "Organizational Innovation: A Meta-Analysis Of Effects Of Determinants and Moderators," Acad. Manag. J., vol. 34, no. 3, pp. 555-590, 1991.

[22] R. F. Hurley and G. T. M. Hult, "Innovation, Market Orientation, and Organizational Learning: An Integration and Empirical Examination," J. Mark., vol. 62, no. 3, p. 42, Jul. 1998.

[23] S. Yamin, A. Gunasekaran, and F. T. Mavondo, "Relationship between generic strategies, competitive advantage and organizational performance: an empirical analysis," Technovation, vol. 19, no. 8, pp. 507-518, 1999.

[24] M. Baer and M. Frese, "Innovation is not enough: climates for initiative and psychological safety, process innovations, and firm performance," J. Organ. Behav., vol. 24, pp. 45-68, 2003. 